\title{
Research on the Engineering Practice Teaching Effect and Influencing Factors of the Modern Distance Education Relation Model based on the Factor Analysis
}

\author{
Zhang Jing \\ dept. of Professional teachers center \\ school of remote and continuing education of DUT \\ DaLian, China \\ net3@dlut.edu.cn \\ Tian Dan \\ dept. of Professional teachers center \\ school of remote and continuing education of DUT \\ DaLian, China \\ network2@dlut.edu.cn
}

\author{
Li Ming-li \\ dept. of Professional teachers center \\ school of remote and continuing education of DUT \\ DaLian, China \\ net14@dlut.edu.cn
}

\begin{abstract}
The education practice of the modern distance education is an important execution mode for the practical talent training mode. The effect of the practice teaching is measure of the practice teaching quality, and the research of the influence factors of it is an important approach to improve the teaching effect. For the purpose of improving the modern distance education engineering practice teaching effect, the influence factors on improving the teaching effect are researched in this paper. The initial model system of the influencing factors of the modern distance education engineering practice teaching effect is carried out. The system multidimensional variables and research hypothesis are detailed described. Combined with impact factor of the model analysis and empirical correction, a more effective modern distance education system of engineering practice teaching effect and influencing factors of the relational model is built. The research results can provide research idea and basis for improving the practice teaching effect
\end{abstract}

Keywords-Modern distance eadcation; Engineering practice; Influnce factor; Model construction.

\section{INTRODUCTION}

The training goal of the modern distance education is positioned to be the training of the practical talents, and the requirement of the actual application ability is highlighted The students attending the distance education are mainly employees, so they all have the requirements for practical and ability to participate in practice ${ }^{[1]}$. Therefore, the practice teaching becomes an important implementation for the modern distance education training mode, and its practice teaching effect will directly affect the quality of modern distance education engineering professional talent training.

Due to the characteristics of the separation of the space and time of the modern distance education, the complete of the teaching process is more complex than the general education. So the influence factor and the restraining factor is also larger than the general education. This requests the researches to research the problems existing in the network education of engineering practice teaching further systematically. It also requires the researchers to discuss the restrict factors for the engineering practice teaching and construct reasonable relation model of the teaching effect and influence factor of the modern distance education. These researches can supply evidence for the promoting of the practical teaching method.

\section{ANALYSIS OF THE INFLUENCE FACTORS}

\section{A. The teaching quality guarantee}

The modern distance education makes the teaching system from the traditional one person mode into the manmachine model because of the intervention of the multimedia technology. The network courseware in teaching is an important way of promoting the students to acquire knowledge, and the teaching courseware becomes the virtual classroom ${ }^{[2]}$. But in other words, this teaching mode brings the separation between teachers and students, and teachers can not directly solve the problem of students face to face. Tutors play an essential role, help students to study and explain briefly the engineering professional knowledge, and solve the practical problems in students learning ${ }^{[3]}$. The matched teaching materials and diverse learning can guide students to carry out professional class learning, and at the same time, the reasonable examination can effectively measure the effect of the course ${ }^{[4]}$.

The operation ability and practical application are particularly attention by the practice teaching of the science and engineering. But these requirements are relatively less than the real classroom. So the school provides a number of safeguards to improve the single teaching mode. The face to face teaching and collaborative learning have achieved results during the practical teaching classroom ${ }^{[5]}$. Modern distance education in science and 
engineering practice is also a variety of teaching method with a variety of forms such as experiment, practice as well as curriculum design. It makes the course tasks actualization and contextualization as far as possible and gives students more suitable learning methods. This teaching method can provided important guarantee for the distance education practice teaching, and decisively influenced the learning effect.

The distance education students are demanded higher requirements to browse the smooth degree of resources. Especially for the link of science and engineering practice teaching, the actual operation and formula all need big data space. Long time buffer can make the operation not coherent and the construction scene hysteretic, so that the teaching effect would be greatly affected. Today, wireless communication technology for modern distance education has opened up a new era. A variety of scanning way can help students study online or download network resources more convenient. The advantage of iOS, Android, Windows Phone all appeared in the using of the network resources. The learners can use their mobile device to receive and send their learning resources at any time, and attend real-time discussion learning, etc. The advantages of autonomous learning and better teaching effect can be achieved $^{[6,7]}$.

\section{B. The teaching content}

During the teaching of the modern distance education, the students can grasp complete knowledge of ascension through the teaching content. The teaching content mainly include all kinds of basic and professional curriculum experiment practice content design content of learning content and assessment content, etc ${ }^{[8]}$. The course content should be set combining the professional characteristics and the needs of students. The students can obtain their value in the study gradually. This teaching mode has a certain promotion and the effectiveness of practice teaching to the remote education, and it also has great help to students' career planning ${ }^{[9]}$.

\section{Teaching interactiont}

The modern distance education teaching learners can obtain the teacher's teaching course content by careful study. The knowledge can be strengthened during the learning of the homework and the interaction between the teachers and the students. The students can get guidance and the teachers can get feedback from this interaction. And this process can greatly promote the teaching optimization ${ }^{[10]}$.

During the study of the network education, answering questions and mentoring is the important way of communication between students and teachers. The course BBS extends the network virtual classroom qualified by the speaker teachers. Especially for the science and engineering subject, the stronger practical characteristics makes it's hard to explain the detailed operation and the real construction in the original teaching. But with the help of the interactive communication in the course forum, the actual problem can be solved and better teaching effect can be achieved. For some high schools with better teaching situations, the face-to-ace communication and video mentoring can be supported to solve problems. Further more, a teaching mode named collaborative learning with better teaching effect can be got now. The students can promote the study effect during the team or between each team, and the study effect would be greatly improved. Better study effect can be got with higher interaction rate and more online learning time ${ }^{[11]}$.

\section{Learning motivation}

In the practical teaching of the modern distance education, the learning motivation is the source power promoting students' learning. It plays important role in the exciting, strengthen, and maintaining of the study, and it also restricts the study process.

The network learning motivation mainly involves three aspects , which are epistemic motivation, selfimprovement motivation and the personal interest in knowledge ${ }^{[12]}$. The modern distance education students primarily come from professionals including construction organization, factory, company, etc. The students in science and engineering fields interact mutually and restraining each other. So for science and engineering practice teaching, better learning requires the subject the students learning should match the job they worked for. Self-improvement motivation is widespread in the actual teaching. Especially for the initial degree with lower management or professionals with weak foundation, the motivation of learning for personal ascension will yield better results. The teacher and student are separated, so the less of the teacher's supervision makes the personal interest be the first factor that influences the study. The student with higher motivation usually has higher motivation and stronger consciousness while that with lower motivation should be paid more attention ${ }^{[13]}$. Motivation of positive or not directly influences the teaching effect of modern distance education in science and engineering.

\section{CONSTRUCTION OF THE PRACTICE TEACHING \\ EFFECT AND INFLUENCING FACTORS OF THE MODERN DISTANCE EDUCATION RELATION MODEL}

\section{A. Figure Design}

Based on the analysis of the influence factors discussed above and combined with the research of the original data, the figures of the practice teaching effect and influencing factors with pertinence and effectiveness can be designed, as shown in Table 1 and Table 2 .

The teaching security contained about 20 indicators including period, teaching level, experimental type, resources browsing, etc. And each indicator all belongs to contemporary and long-range education teaching security factors in the practical teaching, as shown in Fig .1. Each indicator is obtained from the former research [2-7], and also combined with the expert interviews. The teaching content contains 8 indicators, and they are obtained from the former research [8-9] and the actual research of the professional teachers. The teaching interaction also contains 8 indicators, and they are obtained from the former research $[5,10,11]$ and the research of the professional teachers and the students. The students' study motivation to learn contains 3 indicators, and they are obtained from the former research $[12,13]$ and the interview of the professional teachers.

Because of the particularity of the science and engineering and the distance education, the practice teaching effect of the modern distance education mainly 
characterized by the ability of the students including the training effect of the basic ability ${ }^{[14]}$, the training effect of the professional comprehensive ability ${ }^{[15]}$, the training effect of the vocational ability ${ }^{[16]}$, as listed in Table 2 .

TABLE I. THE INFLUENCING FACTORS OF THE MODERN DISTANCE EDUCATION PRACTICE TEACHING EFFECT

\begin{tabular}{|c|c|c|}
\hline $\begin{array}{c}\text { Dimension } \\
\text {-ality }\end{array}$ & Index & $\begin{array}{c}\text { Sourc- } \\
\text { es }\end{array}$ \\
\hline $\begin{array}{l}\text { Course } \\
\text { guarantee }\end{array}$ & $\begin{array}{l}\text { schedules, credits, network } \\
\text { courseware, teaching level, book, } \\
\text { diversification teaching, face to } \\
\text { award coach, practice base, } \\
\text { collaborative learning, } \\
\text { demonstrative experiment, virtual } \\
\text { experiment, distance controlling } \\
\text { experiment, actual experiment, } \\
\text { practical, course design, graduate } \\
\text { design, inspection form, smoothly } \\
\text { read resources, diversification } \\
\text { resources reading }\end{array}$ & {$[2-7]$} \\
\hline $\begin{array}{l}\text { Teaching } \\
\text { content }\end{array}$ & $\begin{array}{l}\text { public elementary courses, major } \\
\text { elementary course, laboratory } \\
\text { course, course design, graduate } \\
\text { design, practice, guidance on } \\
\text { learning, examination }\end{array}$ & $\begin{array}{l}{[8]} \\
{[9]}\end{array}$ \\
\hline $\begin{array}{c}\text { Teaching } \\
\text { interaction }\end{array}$ & $\begin{array}{l}\text { learning network courseware, } \\
\text { reading assorted materials , } \\
\text { downloading the learning guide } \\
\text { information, completing the } \\
\text { homework, bbs communication, } \\
\text { participating in answering } \\
\text { questions, participating in the face } \\
\text { to award coach, participating in } \\
\text { collaborative learning }\end{array}$ & $\begin{array}{c}{[6]} \\
{[10]} \\
{[11]}\end{array}$ \\
\hline $\begin{array}{l}\text { Learning } \\
\text { motivation }\end{array}$ & $\begin{array}{l}\text { the major matches the work, } \\
\text { improve self, interestingr }\end{array}$ & $\begin{array}{l}{[12]} \\
{[13]}\end{array}$ \\
\hline
\end{tabular}

TABLE II. THE CHARACTERIZE OF THE MODERN DISTANCE EDUCATION PRACTICE TEACHING EFFECT

\begin{tabular}{|l|l|}
\hline Index & Sources \\
\hline acquire knowledge, ability to integrate & \\
theory with practice, practical operation & \\
ability, innovation ability, specialty literacy, & \\
professional skill, analysis solution actual & [14-16] \\
problem ability, professional quality, post & \\
employment ability, development of & \\
professional competency, professional & \\
development ability, learners' satisfaction & \\
\hline
\end{tabular}

\section{B. Research hypothesis and model construct}

40 researches hypothesize are summarized as below:

Hypothesis HBZ: The 20 teaching safeguard effect factors named BZ1-BZ20 are all have significant positive influence to the practical teaching effect of the modern distance education.

Hypothesis HNR: The 9 teaching content effect factors named NR1-NR9 are all have significant positive influence to the practical teaching effect.
Hypothesis HHD: The 8 teaching interdynamic effect factors named HD1-HD8 are all have significant positive influence to the practical teaching effect.

Hypothesis HNR: The 3 learning motivation effect factors named DJ1-DJ39 are all have significant positive influence to the practical teaching effect.

According to the research hypothesize discussed above, the initial hypothesize model of the practice teaching effect and influencing factors as shown in Fig .1. It can be seen from Fig .1 that, 4 factors are contained in this model which is teaching guarantee, teaching content, teaching interaction and learning motivation. And corresponding number of indexes are further used to describe each dimension. The end aim is improving the practical teaching effect of the modern distance education which is character by several varieties named XG1-XG11.

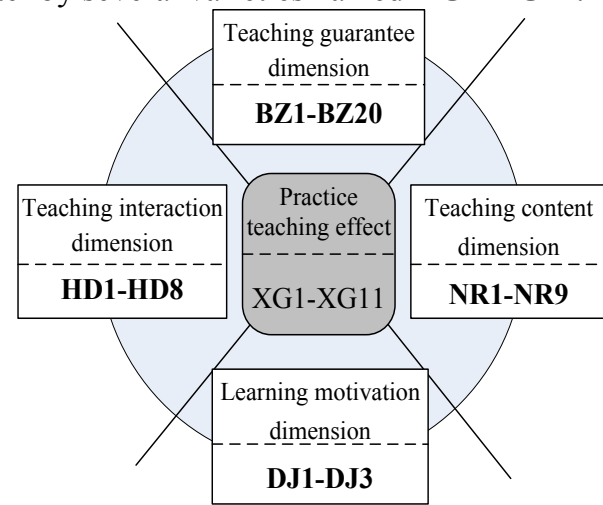

Figure 1. Initial relation model

\section{RESEARCH ON THE MODEL AMENDMENT}

\section{A. Questionnaires}

The questionnaires are composed by 3 parts including the statistics of the respondents' information characteristics, the influence factors if this model and the factors impressing the teaching effect. The internationally accepted Likert5 scale method is adopt in which 5 represents to exactly match and 1 represents to totally unsuited. In this paper, the Dalian University of Technology and the Shandong University are chosen to make the sampling data samples. 900 questionnaires are given out, and 757 effective questionnaires are recovered, so the effective recovery rate is $84.1 \%$.

\section{B. Factor analysis}

In this paper, the value of KMO is firstly used to check whether the sample data is suitable for the EFA analysis. The value of KMO is set to be $0-1$. When all the variables of simple correlation coefficient between sums of squares are far greater than the sum of squares partial correlation coefficient, the KMO value is close to 1 . And this result means that the pertinence is much stronger, and the original variable is more suitable for factor analysis. The KMO value of this research is 0.940 and $\mathrm{P}<0.001$ by the analysis of the SPSS software ${ }^{[17]}$. This result shows that the research data is suitable for this research. Therefore, in this study 51 indicators for public factor are extracted, and the factor loading matrix is obtained by maximum variance orthogonal rotation method, as shown in table 3. Among 
TABLE III THE FACTOR LOADING MATRIX AFTER ROTATION

\begin{tabular}{|c|c|c|c|c|c|c|c|c|c|c|}
\hline \multirow{2}{*}{ Factors } & \multirow{2}{*}{ Variable } & \multicolumn{9}{|c|}{ Component } \\
\hline & & 1 & 2 & 3 & 4 & 5 & 6 & 7 & 8 & 9 \\
\hline \multirow{10}{*}{$\begin{array}{c}\text { F1: } \\
\text { Course security } \\
\text { situational } \\
\text { factor }\end{array}$} & BZ11 & 0.761 & 0.144 & -0.041 & 0.152 & 0.089 & 0.165 & 0.035 & 0.049 & 0.048 \\
\hline & BZ12 & 0.759 & 0.19 & 0.065 & 0.168 & 0.011 & 0.117 & 0.046 & 0.09 & -0.021 \\
\hline & BZ9 & 0.71 & 0.132 & 0.222 & 0.07 & 0.249 & -0.025 & 0.15 & 0.111 & 0.038 \\
\hline & BZ14 & 0.707 & 0.102 & 0.3 & 0.041 & 0.063 & 0.04 & 0.133 & 0.241 & 0.042 \\
\hline & BZ10 & 0.705 & 0.148 & 0.223 & 0.099 & 0.136 & 0.027 & 0.16 & 0.103 & 0.086 \\
\hline & BZ15 & 0.681 & 0.084 & 0.308 & -0.007 & 0.088 & 0.046 & 0.24 & 0.282 & 0.001 \\
\hline & BZ13 & 0.678 & 0.046 & 0.114 & 0.171 & 0.132 & 0.194 & 0.027 & 0.165 & 0.095 \\
\hline & BZ7 & 0.603 & 0.139 & 0.239 & 0.106 & 0.313 & 0.022 & 0.11 & 0.031 & -0.006 \\
\hline & BZ16 & 0.531 & 0.14 & 0.227 & 0.069 & 0.114 & 0.118 & 0.222 & 0.443 & 0.085 \\
\hline & BZ17 & 0.529 & 0.113 & 0.235 & 0.077 & 0.105 & 0.067 & 0.177 & 0.122 & 0.079 \\
\hline \multirow{8}{*}{$\begin{array}{c}\text { F2: } \\
\text { Characterization } \\
\text { of practice } \\
\text { teaching effect }\end{array}$} & XG6 & 0.108 & 0.766 & 0.036 & 0.057 & 0.138 & 0.106 & 0.105 & 0.098 & 0.047 \\
\hline & $\mathrm{XG} 2$ & 0.098 & 0.725 & 0.118 & 0.145 & 0.1 & 0.092 & 0.085 & 0.074 & 0.281 \\
\hline & XG3 & 0.107 & 0.722 & 0.124 & 0.148 & 0.101 & 0.021 & 0.044 & 0.129 & 0.171 \\
\hline & $\mathrm{XG} 4$ & 0.167 & 0.72 & 0.145 & 0.095 & 0.144 & 0.096 & 0.155 & 0.139 & 0.05 \\
\hline & XG8 & 0.118 & 0.712 & 0.124 & 0.149 & 0.165 & 0.085 & 0.152 & 0.051 & 0.077 \\
\hline & XG5 & 0.144 & 0.708 & 0.077 & 0.092 & 0.095 & 0.137 & 0.102 & 0.146 & 0.11 \\
\hline & XG7 & 0.119 & 0.696 & 0.102 & 0.091 & 0.13 & 0.205 & 0.061 & 0.034 & 0.084 \\
\hline & XG1 & 0.199 & 0.500 & 0.146 & 0.133 & 0.032 & 0.088 & 0.092 & 0.063 & 0.449 \\
\hline \multirow{4}{*}{$\begin{array}{l}\text { F3: } \\
\text { Classroom } \\
\text { interaction }\end{array}$} & HD7 & 0.278 & 0.186 & 0.773 & 0.125 & 0.111 & 0.223 & 0.166 & 0.127 & 0.079 \\
\hline & HD6 & 0.298 & 0.239 & 0.725 & 0.149 & 0.103 & 0.221 & 0.125 & 0.034 & 0.1 \\
\hline & HD8 & 0.302 & 0.23 & 0.693 & 0.121 & 0.036 & 0.185 & 0.105 & 0.159 & 0.141 \\
\hline & HD5 & 0.298 & 0.193 & 0.627 & 0.15 & 0.128 & 0.311 & 0.102 & -0.024 & 0.048 \\
\hline \multirow{4}{*}{$\begin{array}{l}\text { F4: } \\
\text { Course content }\end{array}$} & NR2 & 0.198 & 0.204 & 0.058 & 0.767 & 0.099 & 0.175 & 0.126 & 0.116 & 0.077 \\
\hline & NR3 & 0.159 & 0.265 & 0.168 & 0.712 & 0.162 & 0.102 & 0.19 & 0.14 & -0.044 \\
\hline & NR1 & 0.209 & 0.182 & 0.116 & 0.642 & 0.116 & 0.195 & 0.09 & 0.307 & 0.016 \\
\hline & NR4 & 0.278 & 0.187 & 0.147 & 0.546 & 0.129 & 0.066 & 0.39 & 0.078 & 0.058 \\
\hline \multirow{8}{*}{$\begin{array}{c}\text { F5: } \\
\text { Curriculum } \\
\text { system security }\end{array}$} & BZ3 & 0.043 & 0.17 & 0.107 & 0.017 & 0.740 & 0.091 & 0.098 & 0.077 & 0.101 \\
\hline & BZ4 & 0.219 & 0.174 & 0.104 & 0.186 & 0.687 & 0.143 & -0.004 & 0.111 & 0.146 \\
\hline & BZ5 & 0.234 & 0.131 & 0.071 & 0.176 & 0.628 & 0.094 & 0.084 & 0.082 & 0.14 \\
\hline & BZ6 & 0.26 & 0.257 & -0.032 & 0.024 & 0.621 & 0.031 & 0.218 & 0.073 & 0.029 \\
\hline & BZ8 & 0.36 & 0.204 & 0.167 & 0.043 & 0.566 & 0.041 & 0.077 & 0.059 & 0.184 \\
\hline & BZ1 & 0.106 & 0.035 & -0.018 & 0.186 & 0.545 & 0.16 & 0.031 & 0.108 & 0.011 \\
\hline & BZ2 & 0.324 & 0.107 & 0.027 & 0.08 & 0.537 & 0.11 & 0.063 & 0.272 & 0.066 \\
\hline & BZ18 & 0.393 & 0.169 & -0.002 & 0.049 & 0.512 & 0.112 & 0.204 & 0.079 & 0.112 \\
\hline \multirow{4}{*}{$\begin{array}{l}\quad \text { F6: } \\
\text { After class } \\
\text { interaction }\end{array}$} & HD3 & 0.182 & 0.126 & 0.179 & 0.099 & 0.108 & 0.763 & 0.101 & 0.061 & 0.114 \\
\hline & HD4 & 0.064 & 0.093 & 0.192 & 0.056 & 0.128 & 0.718 & 0.106 & 0.081 & 0.147 \\
\hline & HD2 & 0.238 & 0.181 & 0.157 & 0.189 & 0.027 & 0.686 & -0.005 & 0.035 & 0.185 \\
\hline & HD1 & 0.086 & 0.289 & 0.117 & 0.105 & 0.13 & 0.622 & 0.255 & 0.038 & 0.104 \\
\hline \multirow{5}{*}{$\begin{array}{l}\text { F7: } \\
\text { Course } \\
\text { auxiliary } \\
\text { content }\end{array}$} & NR8 & 0.201 & 0.23 & 0.093 & 0.096 & 0.173 & 0.265 & 0.729 & 0.133 & 0.048 \\
\hline & NR9 & 0.101 & 0.341 & 0.143 & 0.101 & 0.24 & 0.328 & 0.62 & 0.142 & -0.044 \\
\hline & NR7 & 0.366 & 0.178 & 0.102 & 0.358 & -0.019 & 0.067 & 0.589 & 0.095 & 0.135 \\
\hline & NR6 & 0.151 & 0.138 & 0.207 & 0.333 & 0.169 & 0.054 & 0.582 & 0.192 & 0.252 \\
\hline & NR5 & 0.262 & 0.122 & 0.192 & 0.464 & 0.073 & -0.014 & 0.523 & 0.059 & 0.293 \\
\hline \multirow{2}{*}{$\begin{array}{l}\text { F8: Technical } \\
\text { guarantee }\end{array}$} & BZ19 & 0.097 & 0.244 & -0.004 & 0.188 & 0.158 & 0.009 & 0.034 & 0.716 & 0.088 \\
\hline & BZ20 & 0.248 & 0.103 & 0.083 & 0.317 & 0.199 & 0.063 & 0.036 & 0.610 & 0.043 \\
\hline \multirow{3}{*}{$\begin{array}{l}\text { F9:Learning } \\
\text { motivation }\end{array}$} & DJ2 & -0.014 & 0.203 & 0.07 & 0.029 & 0.182 & 0.236 & 0.095 & 0.053 & 0.751 \\
\hline & DJ1 & 0.058 & 0.216 & 0.014 & -0.037 & 0.126 & 0.246 & 0.109 & 0.141 & 0.671 \\
\hline & DJ3 & 0.133 & 0.408 & 0.177 & 0.129 & 0.166 & 0.036 & 0.046 & 0.062 & 0.601 \\
\hline
\end{tabular}


these factors, 9 factors with the value greater than 1 , the cumulative variance contribution rate is $64.75 \%$ can explain $64.75 \%$ of the total variance, the results of factor analysis is more ideal.It can be seen from Table 3 that, in addition to the three item in the practice teaching effect factor on the factor load of smaller $(<0.5)$ be deleted, all the other 48 indicators in place factor has high factor loading $(>0.5)$, and each factor has been accepted.

F1 contains 10 indexes (BZ7, BZ9-BZ17) as shown in Table 3 and it can be named to be course security situational factor. F2 contains 8 indexes (XG1-XG8) and it is the characterization of practice teaching effect. F3 contains 4 indexes (HD5-HD8) and it can be named to be classroom interaction. F4 contains 4 indexes (NR1-NR4) and it can be named to be course content. F5 contains 8 indexes (BZ1-BZ6, BZ8, and BZ18) and it can be named to be curriculum system security. F6 contains 8 indexes (HD1-HD4) and it can be named to be after class interaction. F7 contains 5 indexes (NR5-NR9) and it can be named to be course auxiliary content. F8 contains 2 indexes (BZ19-BZ20) and it can be named to be the technical guarantee. F9 contains 3 indexes (DJ1-DJ3) and it can be named to be learning motivation.

\section{Model correction}

The initial model is corrected according to the factor analysis, as shown in Fig .2.

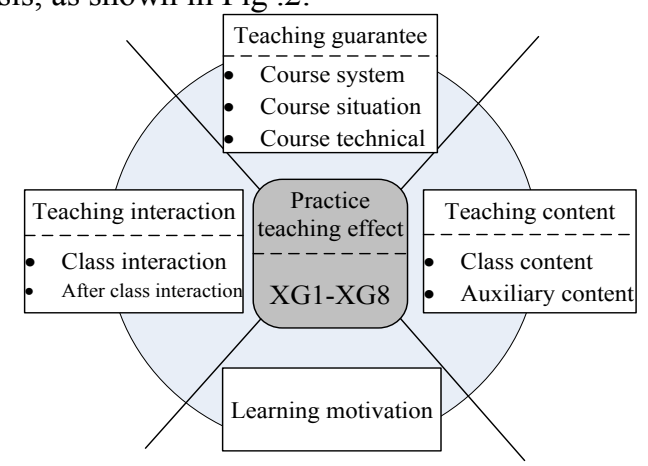

Figure 2. Correction model

51 rambling data are collected to analyze this model. The small correlation variables are cut out and reasonable model representation of variables are collected. The result shows that 40 assumptions of the research hypothesis are accepted, so these 40 assumptions are all have positive effect on the practice teaching effect.

The common properties of the above-mentioned 40 are found, and eight representative main influence factors are obtained. And then these common factors are renamed, and the modern distance education engineering practice teaching effect and the influence factor relation model is reframed. The practice teaching effect can be characterized through 8 main factors shown in table 3 . The mainly influence factors of practical teaching can be effective characterized to be the course security situational factor, security course situation, technical guarantee, after class interaction, classroom interaction, course content, course auxiliary content, learning motivation.

\section{CONCLUSION}

Practice is the essential characteristics of engineering and the practice teaching is an effective way to promote the teaching quality of engineering education. In this paper, for the purpose of promoting the teaching effect of the modern distance education, the influence factors of the teaching effect are analyzed in detail. After the research hypothesis and factor analysis, 40 hypotheses which have positive influence on the teaching effect are researched, and then 8 main impact factors are obtained. So a more efficient modern distance education engineering practice teaching effect and influencing factors of the relational model is constructed. These results can provide guidance to for the study of the modern distance education practice teaching effect promotion methods. And they can also provide indicators and resource basis for the practical teaching effect evaluation.

\section{ACKNOWLEDGMENT}

The work described has not been submitted elsewhere for publication, in whole or in part. This work was supported by the research subject of the modern distance education reform and development.

\section{REFERENCES}

[1] Qin Xiaokang, You Changyong, Hu Huilong. Research on the Model of E- learning[J]. Modern Distance Education, 2005(1)

[2] Zhang Jing, Mei Yu, Li Ming-li, Construction of the engineering experimental teaching system for remote education based on the model analysis, IEEE Press, Api. 2012, pp. 1728-1734

[3] He Jian-min, Chen Cheng, Yang Shan-lin. "Independent + cooperative + innovation" network learning process modeling $[\mathrm{J}]$. Journal of Hefei University of Technology,, 2009, 32 (7)

[4] Liu Qiang, Electricity class higher vocational practice teaching system of research and practice,[J] China power education. 2010(7).

[5] Zhu Zhi-ting, Wang You-mei, Gu Xiao-qing. Collaborative learning: learning technology system framework for knowledge era [J] China Educational Technology, 2007, 1 (6) .

[6] Yuan Jun. content analysis and case design of Network teaching [J]. Science and technology information, 2007, 19.

[7] Gao Pei. The Researeh of DeveloPment Mode of Adult Web Course [D].Beijing : Beijing Jiaotong University, 2008.

[8] Lee.B.C, Yoon.J.O. and Lee.L.Learners' Acceptance of e-Learning in South Korea:Theories and Results [J]. Computers\&Education , 2009,53 ( 4 ):1320-1329.

[9] YanBing. Online Education of Engineering Prafessianal Training Mode [D].ChangChun: Jilin university, 2013.

[10] Huang Liu-qun. A Study of E-learning's Interactive Instruction Strategy [D]. Xiamen : Xiamen university, 2008.

[11] Gong Zhi-wu. An empirical study on impacting factors of adult learner's online learning behavior $[\mathrm{J}]$. China Educational Technology, (8): 32-35.

[12] Du Sui-hua. The research of Adults participate in online learning motivation [J]. Journal of higher correspondence: philosophy and social sciences, 2010, (7) : 14-17.

[13] Zhang Ping, Tang Guo-ju. The present situation of the domestic network learning motivation research and enlightenment. China medical education technology $[\mathrm{J}], 2011,25(4)$.

[14] Chen Guo-song.The research of Key university undergraduate engineering education practice teaching reform [D].Wuhan : Huazhong university of science and technology, 2012.

[15] Liao Le-yun. The analysis of Practice teaching in higher vocational colleges work influence factors and the present situation [D]. Guangzhou: Guangzhou university, 2012.

[16] Zhang Chun-rong, Shi Xiao-qiu, Lv Le. Applied network oriented on the teaching reform of the practice of talent training. Journal of university of electronic science and technology $[\mathrm{J}], 2008,10(4)$

[17] Guo Zhi-gang. Social statistics analysis method- the application of SPSS software [M]. Beijing China people's university press, 1999, 12. 